\title{
Flowering, Fruit Set, Development, Size, and Quality of Satsuma Mandarin as Affected by Oxygen Content of Soil Atmosphere
}

\author{
Kazuo IwASAKI \\ College of Agriculture, Ehime University, Matsuyama
}

\begin{abstract}
Summary
1. This experiment was conducted to examine the effects of oxygen levels of soil atmosphere on flowering, fruit set, growth and quality of Satsuma mandarin. Oxygen concentration in the soil air was maintained at five levels, i. e., 20 (air), 10, 5,2 and 0 (nitrogen gas) per cent by mixing air with nitrogen gas.

2. Lower levels of soil oxygen maintained around the rhizosphere from April 9, immediately after sprouting, to May, before flowering, exerted significant effects on the flowering time and blossom production. No flowers attained the full state of bloom at the 2 or 0 per cent soil oxygen levels.

3. When the soil oxygen concentration was kept low from the fruit set to harvest time, the tree growth, fruit development, sugar content in the juice, and carotenoid content in the peel were markedly depressed, except that the acid content in the juice was increased at the harvest time. In the post-bloom treatment, however, higher sugar and carotenoid content and lower acid content were observed only at 0 per cent oxygen concentration.

4. At the end of the experiment, $\mathrm{N}, \mathrm{K}$ and $\mathrm{Ca}$ concentrations in the leaves of pre-bloom treatment and N, P, K and $\mathrm{Ca}$ of post-bloom treatment were lowered when grown under low soil oxygen supply.
\end{abstract}

\section{Introduction}

Fruit trees planted in a field with heavy subsoil profiles tend to display unsatisfactory growth $(1,3)$. It is evident that one of the causes of suppressed tree growth is inadequate soil aeration associated with low soil porosity and poor drainage. In apples, poor aeration necessarily decreases the supply of oxygen to the rhizosphere and concequently limit the depth and ramification of root systems (21, 23).

In the controlled soil atmosphere experiments $(5,6,7,8,9,12,13,20)$ growth and nutrient absorption of various fruit trees were considerably depressed by low oxygen supply in the soil. It was also shown in a previous paper (8) that tree growth, nutrient absorption and root respiration rate of non-bearing citrus trees were markedly reduced by low oxygen concentrations in the soil atmosphere. In particular, most nutrient elements such as $\mathrm{P}, \mathrm{K}, \mathrm{Ca}$ and $\mathrm{Mg}$ were usually

\footnotetext{
Received for publication October, 14, 1974.
}

absorbed in less amounts than N. In the present paper, therefore, the author intended to examine the effect of oxygen concentration of soil air on the flowering, fruit set, development, size and quality of Satsuma mandarin.

\section{Materials and methods}

The trees used in this experiment were 4year-old fruit bearing Satsuma mandarin (Nankan No. 4) of uniform size. In early March, 1968, they were transplanted from small unglazed pots into 15 liter porcelain pots filled with granitic soil. Each tree was fertilized in mid March with $2 \mathrm{~g} \mathrm{~N}$ (ammonium sulphate), $1 \mathrm{~g} \mathrm{P}_{2} \mathrm{O}_{5}$ (fused phosphate), $2 \mathrm{~g} \mathrm{~K}_{2} \mathrm{O}$ (potassium chloride), $15 \mathrm{~g} \mathrm{CaO}$ (slaked lime) and $1 \mathrm{~g} \mathrm{MgO}$ (magnesium sulphate).

In the manner described in the previous paper (8), the top of the pot was covered tightly with vinyl film of $0.5 \mathrm{~mm}$ thickness cn April 9. The air of these soils was replaced with artificially conditioned air of various oxygen concentrations through an opening on the bottom side of the pot. The conditioned 
air was continuously circulated in each pot throughout the entire period of the experiment. The experiment consisted of 20 (air), 10, 5, 2 and 0 (nitrogen gas) per cent oxygen treatments. Prepared pots were divided into halves and used in the following two series of experiments.

Experiment I. pre-bloom treatment.

The effects of soil oxygen concentration on the flowering time and fruit set were observed in this series. Treatments were continued for about 40 days from April 9, immediately after sprouting, to May 17, just before the onset of first flower opening. The flowering percentage was based, in calculation, on the total number of flower buds borne on each tree. Flower bud counts were started just prior to the onset of first flowering. Flowering counts were made every day from May 17 to May 27. The percentage of fruit set was determined on August 24, about 90 days after full bloom. On May 18, the treatment was ceased, removing vinyl film covers from the pots. After the removal of trees from the pots, total fresh weight of trees and diameter and weight of fruit were measured at the harvest time. Total and reducing sugars in the juice were chemically analyzed by the Somogy-Nelson method. Acid content in the juice was expressed as citric acid equivalent after being titrated with $0.1 \mathrm{~N}$ sodium hydroxide. Carotenoids in the peel were extracted with aceton and their absorbance at $440 \mathrm{~m} \mu$ was determined by the Hitachi EPU$2 \mathrm{~A}$ photo-electric spectrophotometer.

Leaf analysis for $\mathrm{N}, \mathrm{P}, \mathrm{K}, \mathrm{Ca}$ and $\mathrm{Mg}$ was made by the following methods; i.e., $\mathrm{N}$ by the semimicro-Kjeldahl method; $\mathrm{P}$ by the Deniges method; $\mathrm{K}, \mathrm{Ca}$ and $\mathrm{Mg}$ by means of Hitachi RA-1 atomic absorption spectrophotometer.

Experiment II. Post-bloom treatment.

To examine the effect of soil oxygen concentration on fruit growth and quality, the aeration treatment was continued from May 28, 10 days after fruit set, to December 10, harvest time. The other experimental procedures except the duration of artificially conditioned aeration were the same as those described in experiment 1 .

\section{Results}

1. Flowering and fruit set.

The effect of soil oxygen concentration on flowering is illustrated in Fig. 1. From the results obtained in the soil aeration experiment carried out from the time immediatly after sprouting to the time just before flowering, it can be concluded that the soil air of lower oxygen concentrations retarded the flowering time more, and decreased the percentage of flowering more than that of higher oxygen concentrations. At 20 and 10 per cent of soil oxygen the trees attained full bloom from 6 to 8 days after the first flowering, whereas at 5 per cent the time of full bloom was delayed by 2 days. No full blossoms were attained on any trees treated with 2 and 0 per cent of oxygen supply. As shown in Table 1 , fruit set was also depressed within the range of less than 5 per cent oxygen concentration. In particular, no fruit was set at all in the case of 0 per cent soil oxygen concentration.

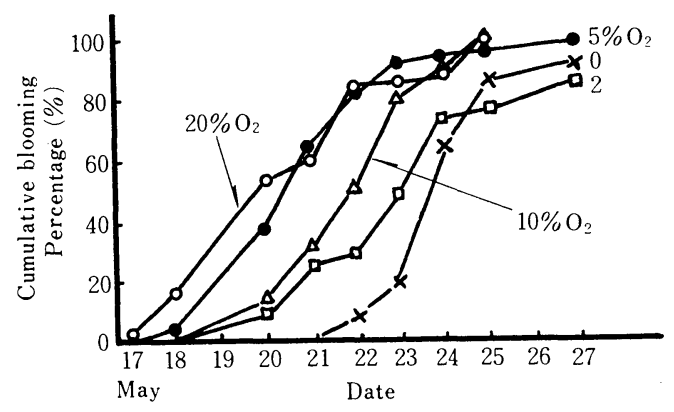

Fig. 1. Cumulative blooming percentage as affected by soil oxygen concentration in the experiment $I$.

Table 1. Fruit set percentage as affected by soil oxygen concentration in the experiment I.

\begin{tabular}{c|c}
\hline Treatment & Fruit set \\
\hline $20 \% \mathrm{O}_{2}$ & $8.9(i 00)$ \\
10 & $8.7(97)$ \\
5 & $5.1(57)$ \\
2 & $2.7(30)$ \\
0 & $0(0)$ \\
\hline
\end{tabular}

2. Fruit growth and quality.

The curves of fruit growth in terms of 
transverse diameter are shown in Fig. 2. In mid July, no differences in diameter could be observed between each treatment. In early August, however, the delay of fruit growth occurred at 0 per cent of soil oxygen. The increment of fruit diameter was depressed more by lowering soil oxygen concentrations. Thus, distinct differences among the treatments took place in early October. Such trends continued to the harvest time.

The tree growth, fruit size and quality of treated Satsuma trees are shown in Tables 2,

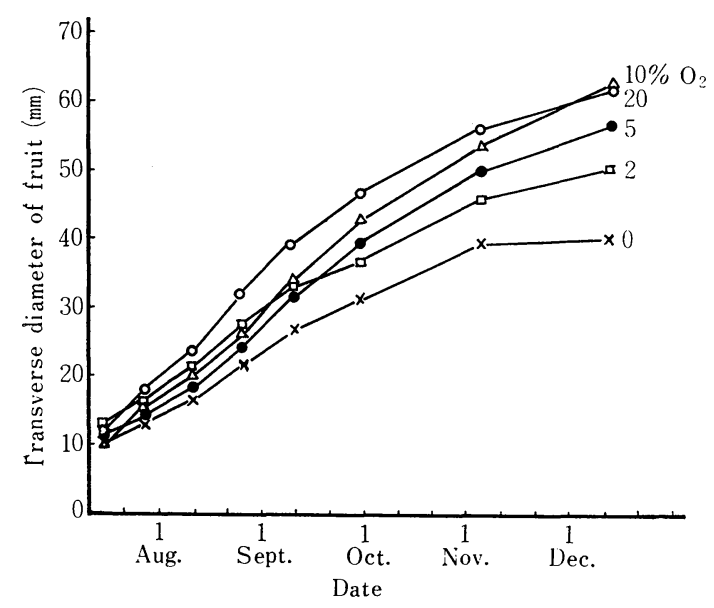

Fig. 2. Cumulative growth curves of Satsuma mandarin fruits as affected by soil oxygen concentration in the experiment II.

Table 2. Growth of Satsuma mandarin trees as affected by soil oxygen concentration in the experiment I.

\begin{tabular}{l|c|c|c}
\hline \hline Treatment & $\begin{array}{l}\text { Total fresh } \\
\text { wt, }\end{array}$ & Top fresh wt. & $\begin{array}{l}\text { Root fresh } \\
\text { wt. }\end{array}$ \\
\hline & $\mathrm{g}$ & $\mathrm{g}$ & $\mathrm{g}$ \\
$20 \% \mathrm{O}_{2}$ & $878(100)$ & $453(100)$ & $425(100)$ \\
10 & $670(76)$ & $362(80)$ & $308(72)$ \\
5 & $511(58)$ & $220(49)$ & $291(68)$ \\
2 & $583(66)$ & $180(40)$ & $319(75)$ \\
0 & $339(39)$ & $105(23)$ & $234(55)$ \\
\hline
\end{tabular}

Table 3. Growth of Satsuma mandarin trees as affected by soil oxygen concentration in the experiment II.

\begin{tabular}{l|c|c|c}
\hline \hline Treatment & $\begin{array}{l}\text { Total fresh } \\
\text { wt. }\end{array}$ & Top fresh wt. & $\begin{array}{l}\text { Root fresh } \\
\text { wt. }\end{array}$ \\
\hline & $\mathbf{g}$ & $\mathrm{g}$ & $\mathrm{g}$ \\
$20 \% \mathrm{O}_{2}$ & $745(100)$ & $481(100)$ & $264(100)$ \\
10 & $684(92)$ & $421(90)$ & $253(96)$ \\
5 & $468(63)$ & $266(55)$ & $205(78)$ \\
2 & $557(75)$ & $299(62)$ & $258(98)$ \\
0 & $317(43)$ & $189(39)$ & $125(47)$ \\
\hline
\end{tabular}

3 and 4 , and in Fig. 3. The decrease in total fresh weight of the plants was closely associated with the lowering of oxygen concentrations of soil air in both the pre-bloom and post-bloom treatments.

At oxygen concentrations below 5 per cent, both fruit diameter and fresh weight were more depressed in the post-bloom treatment. The contents of total and reducing sugars in the juice also decreased with lowered oxygen supply except for the 0 per cent level of the post-bloom treatment. Lowering soil oxygen concentrations likewise tended to reduce the carotenoid content of the peel, though in the post-bloom treatment a higher carotenoid content was shown at 0 per cent.

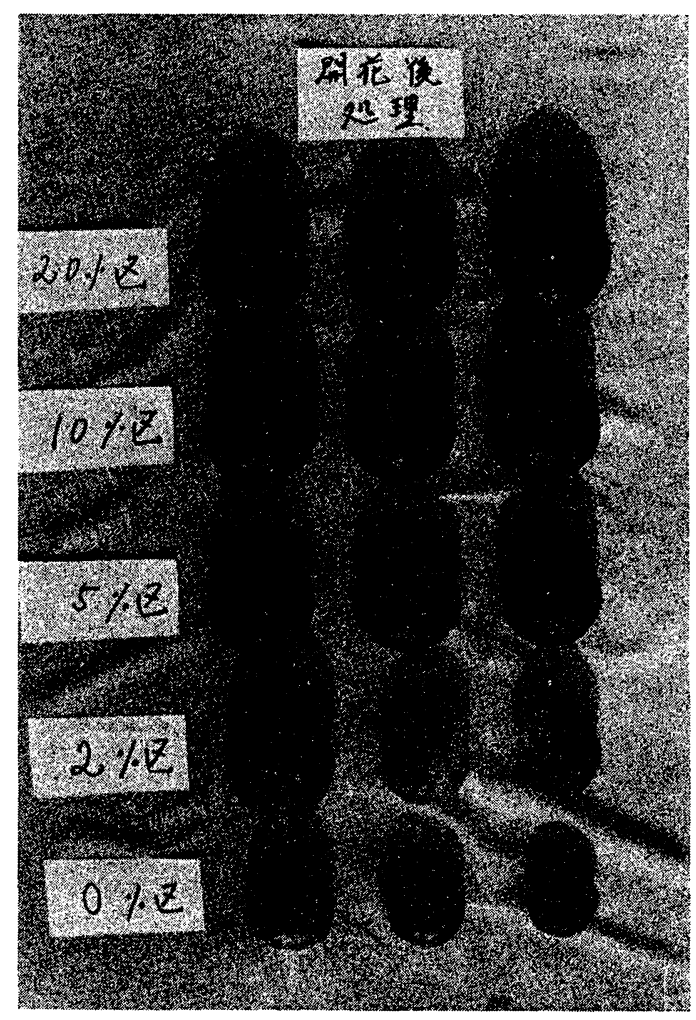

Fig. 3. Effects of soil oxygen concentrations on the growth of Satsuma mandarin fruits in the experiment II.

3. Nutrient content in the leaves.

The results of leaf analysis for $\mathrm{N}, \mathrm{P}, \mathrm{K}, \mathrm{Ca}$ and $\mathrm{Mg}$ are shown in Table 5 . In company with the decrease in soil oxygen concentration, $\mathrm{N}, \mathrm{K}$ and $\mathrm{Ca}$ contents of leaves were decreased in the pre-bloom treatment, though 
Table $\approx$ 4. Fruit growth and quality at harvest time as affected by soil oxygen concentration.

\begin{tabular}{|c|c|c|c|c|c|c|}
\hline Treatment & Diameter & Weight & Total sugars & Reducing sugars & Acids & Carotenoid \\
\hline \multirow{2}{*}{$\begin{array}{c}\text { Experiment I } \\
20 \% \mathrm{O}_{2}\end{array}$} & \multirow{2}{*}{$\begin{array}{l}\mathrm{cm} \\
6.3(100)\end{array}$} & \multirow{2}{*}{$\begin{array}{l}g \\
93\end{array}$} & \multicolumn{3}{|c|}{$\mathrm{g} / 100 \mathrm{ml}$ juice } & \multirow{2}{*}{$\begin{array}{l}\mathrm{mg} / \mathrm{dm}^{2} \\
12.2(100)\end{array}$} \\
\hline & & & $8.8(100)$ & $2.8(100)$ & $1.3(100)$ & \\
\hline 10 & $6.4(101)$ & $104(111)$ & $7.2(82)$ & $2.2(78)$ & $1.4(113)$ & $10.7(88)$ \\
\hline 5 & $6.0(95)$ & $78(84)$ & $6.8(78)$ & $1.1(39)$ & $1.0(78)$ & $10.5(86)$ \\
\hline 2 & $5.6(88)$ & $64(69)$ & $4.8(54)$ & $1.6(59)$ & $1.3(100)$ & $3.5(29)$ \\
\hline 0 & $-\quad-$ & $-\quad-$ & $-\quad-$ & $-\quad-$ & $-\quad-$ & - $\quad-$ \\
\hline \multicolumn{7}{|l|}{ Experiment II } \\
\hline $20 \% \mathrm{O}_{2}$ & $6.2(100)$ & $77(100)$ & $7.8(100)$ & $2.4(100)$ & $1.3(100)$ & $11.6(100)$ \\
\hline 10 & $6.3(102)$ & 88 (115) & $7.6(98)$ & $1.7(72)$ & $1.4(113)$ & $10.4(89)$ \\
\hline 5 & $5.7(92)$ & $69(90)$ & $6.5(84)$ & $2.1(88)$ & $1.6(129)$ & $10.1(88)$ \\
\hline 2 & $5.0(81)$ & $49(63)$ & $5.8(75)$ & $1.6(66)$ & $2.2(172)$ & $2.1(18)$ \\
\hline 0 & $4.0(65)$ & $25(33)$ & $10.1(131)$ & $3.9(164)$ & $0.9(71)$ & $9.9(85)$ \\
\hline
\end{tabular}

Table 5. Nutrient content of Satsuma mandarin leaves as affected by soil oxygen concentration (Dry matter precent).

\begin{tabular}{c|c|c|c|c|c}
\hline Treatment & $\mathrm{N}$ & $\mathrm{P}$ & $\mathrm{K}$ & $\mathrm{Ca}$ & $\mathrm{Mg}$ \\
\hline Experiment I & $\%$ & $\%$ & $\%$ & $\%$ \\
$20 \% \mathrm{O}_{2}$ & $2.07(100)$ & $0.28(100)$ & $1.01(100)$ & $2.45(100)$ & $0.32(100)$ \\
10 & $2.09(101)$ & $0.34(121)$ & $1.16(115)$ & $1.80(73)$ & $0.30(94)$ \\
5 & $1.88(91)$ & $0.36(129)$ & $0.84(83)$ & $2.59(106)$ & $0.28(84)$ \\
2 & $1.58(76)$ & $0.35(125)$ & $0.89(88)$ & $2.33(91)$ & $0.42(128)$ \\
0 & $1.52(73)$ & $0.28(100)$ & $0.90(89)$ & $2.14(87)$ & $0.46(144)$ \\
\hline Experiment II & $\%$ & $\%$ & $\%$ & $\%$ \\
$20 \% \mathrm{O}_{2}$ & $2.15(100)$ & $0.29(100)$ & $0.99(100)$ & $2.55(100)$ & $0.34(100)$ \\
10 & $1.64(76)$ & $0.27(93)$ & $0.80(81)$ & $1.84(72)$ & $0.36(106)$ \\
5 & $1.45(64)$ & $0.28(97)$ & $0.86(87)$ & $2.25(88)$ & $0.36(106)$ \\
2 & $0.94(44)$ & $0.18(62)$ & $0.45(45)$ & $0.91(36)$ & $0.23(68)$ \\
0 & $0.32(15)$ & $0.14(48)$ & $0.18(18)$ & $0.44(17)$ & $0.44(129)$ \\
\hline
\end{tabular}

$\mathrm{N}, \mathrm{P}, \mathrm{K}$ and $\mathrm{Ca}$ were decreased in the postbloom treatment. In general, the nutrient contents in both treatments tended to decrease more in the post-bloom than in the pre-bloom treatment. Ir paritcular, at 2 and 0 per cent of soil oxygen, $\mathrm{N}, \mathrm{P}, \mathrm{K}$ and $\mathrm{Ca}$ in the leaves were markedly decreased in the post-bloom treatment.

\section{Discussion}

Although effects of soil oxygen supply on growth and nutrient content of various kinds of tree fruits have been reported by several investigators, we have now very little information on flowering, fruit set, development and quality of fruit trees affected by low soil oxygen concentrations.

Kobayashi et al. (13) reported with fruiting Delaware grape vines that the treatment of low soil oxygen concentration during the period of 20 days prior to the first flowering greatly retarded the pollen germination and berry set. Especially, no berry set occured oxygen concentrations below 5 per cent. Furthermore, yield, berry growth and quality were reduced in the case of a low oxygen concentration treatment from 15 days after the berry set to the harvest time.

In the present experiment with fruiting Satsuma mandarin trees, both the onset of flower opening and the time of full bloom were retarded at low soil oxygen concentrations in the pre-bloom treatment. When Satsuma trees were grown under low soil oxygen concentrations the decrease in fruit set was similar to that of grape vines. Although fruit set of grapes could not be observed at all in both 5 and 0 per cent of oxygen supplies, that of Satsuma mandarin trees failed only at 0 per cent.

Hartmann and Panetsos (2) reported that under deficient soil moisture conditions, young 
olive trees of any stages from floral primordia formation to full bloom produced fewer flowers than those grown under adeguate soil moisture conditions. The trees, which were subjected to moisture stress for only a short time at different stages of flower development, were affected by almost the same effects, harmful to fruit set, as those subjected to moisture stress throughout the entire period of flower development. Suzuki et al. (22) found that flower production of Satsuma mandarin was considerably decreased by drying treatments at later stages of the development of floral organs.

Kobayashi et al. (10) pointed out that in a grape vine sand culture, the berry set per cluster increased with increasing phosphorus content of cultural solutions. Kobayashi and Ito (11) and Ito and Kobayashi (4) also observed that the flower cluster development, pollen germination and berry set were affected by the internal amino acid content and nitrogenous nutrient status prior to the blooming of grape vines.

In the previous works $(8,9,12)$ with grape vines and citrus trees, the reduction in transpiration rate indicated that water absorption by the roots was noticeably inhibited by lower soil oxygen concentrations in spite of the continuous supply of ample soil moisture. Further, it was found in the same works that the uptake of inorganic nutrients was inhibited by lower soil oxygen concentrations. Labanauskas et al. $(14,16)$ also reported that the concentration and total amount of $\mathrm{N}, \mathrm{K}, \mathrm{Ca}$, $\mathrm{Mg}, \mathrm{Zn}$ and $\mathrm{Fe}$ of citrus seedlings grown at low levels of soil oxygen were more depressed, respectively, than those of seedlings receiving higher oxygen supplies. They also reported that the leaves of citrus seedlings which were subjected to low oxygen supply contained significantly lower amounts of protein amino acids (15). Accordingly, it seems likely that the retardation of flowering and lowered fruit set may result from water stress and consequent poor nutrient absorption caused by decreased soil oxygen supply befor flowering.

With Delaware grapes, Kobayashi et al. (13) found that the growth and quality of berries were lowered greatly as soil oxygen was decreased after berry set. In this paper, the growth and quality of fruit of the lots treated only after fruit set were depressed by lowered soil oxygen concentrations. Among the treatments, however, the highest sugar and the lowest acid contents of juice were observed in the 0 per cent soil oxygen plot. The carotenoid content in the rind was comparatively high in the plot. In the 2 per cent soil oxygen treatment, in contrast, the sugar content was lowest and the acid content highest, and moreover the carotenoid formation was severely retarded.

For these facts it is difficult to propose a possible explanation, but it may be supposed that under the most unfavorable soil condition completely eliminated oxygen the fruit growth is extremely depressed by inadequate supplies of water and nutrient (8), and arrested activity of roots suppressed their function as a sink for the elaborated carbohydrates which are to be translocated to and accumulated in the other plant parts such as leaf, shoot, trunk as well as in fruit. These situations may accelerate fruit maturation, consequently resulting in the fruit with high sugar and low acid contents.

\section{Acknowledgment}

The author wishes to express his thanks to Dr. Kazuo Matsumoto, and Dr. Tadayuki Kuraoka, Professors of Ehime University for valuable suggestions during the course of this work.

\section{Literature Cited}

1. BOYnTON, D. 1938. Concerning the pore space in two orchard soils of different productivity. Proc. Amer. Soc. Hort. Sci. $35: 315$ -319 .

2. Hartman, H.T. and C. Panetsos. 1961. Effect of soil moisture deficiency during floral develpoment on fruitfulness in the olive. Proc. Amer. Soc. Hort. Sci. $78: 209-217$.

3. HEINICK, A. J. and L. P. BATJER. 1931. Difference in soil and tree growth within limited area. Proc. Amer. Soc. Hort. Sci. 27 : 6974 .

4. Iто, M. and K. Kobayashi. 1969. Effect of nutrietion before blooming on the flower cluster development and berry set of grape vines (I). On the $\mathrm{N}$ level in sand culture. Mem. Res. Inst. Food Sci. Kyoto Univ. 
$32: 39-43$.

5. IWASAKI, K. 1965. Growth and nutrient absorption of Delaware grapes as affected by soil oxygen concentrations and nitrogen sources. J. Jap. Soc. Hort. Sci. 34 : 101104.

6.

1966. Growth and nutrient absorption of Delaware grapes as affected by soil oxygen concentrations IV. Comparison of the effect among the different soil properties. J. Jap. Soc. Hort. Sci. $35: 218-224$.

7. 1971. Effect of soil aeration on vine growth and fruit development of grapes. Mem. Coll. Agr. Ehime Univ. 16:1-62.

8. 1972. Studies on growth and nutrient absorption of citrus trees as affected by soil oxygen concentrations. Mem. Coll. Agr. Ehime Univ. $17: 1-12$.

9. and K. KOBAYASHI. 1964. Growth and nutrient absorption of peaches, Satsuma mandarins and Japanese persimmons as effected by the soil oxygen concentration. Agr. and Hort. $39: 55-56$.

10. KobaYASHI, K., T. HosOI, U. IN and S. MizUTANI 1960. The effects of time and level of application of phosphoric acid and potassium on yield and quality of grapes. $\mathrm{J}$. Hort. Asso. Jap. $29: 85-95$.

11. — and M. ITO 1968. Effect of application time of nitrogen in dormant period on the cluster development of Delaware grapes. Mem. Res. Inst. Food Sci. Kyoto Univ. 29: $55-66$.

12. — K. IWASAKI and Y. SATO 1963. Growth and nutrient absorption of grapes as affected by soil aeration I. With non-bearing Delaware grapes. J. Jap. Soc. Hort. Sci. $32: 181-185$.

13. ___ and T. TERANUMA 1963. Pollen germination and berry set, growth and quality of Delaware grapes as affected by soil oxygen concentration. J. Jap. Soc. Hort. Sci. 33 : 266-272.

14. LABANAUSKaS, C. K., L. H. STOLZY and M. F. HANDY 1972. Concentrations and total amounts of nutrients in citrus seedlings (Citrus sinensis Osbec) and in soil as influenced by differential soil oxygen treatment. Soil Sci. Soc. Amer. Proc. $36: 454-457$.
15. and 1972. Protein and non-protein amino acid in citrus leaves as affected by phytophtora spp., root infection and soil oxygen content. J. Amer. Soc. Hort. Sci. $97: 433-436$.

16. and DeWOLFE.

1965. Effect of soil temperature and oxygen on the amounts of macronutrients and micronutrients in citrus seedlings(Citrus sinensis var. Bessie). Soil Sci. Soc. Amer. Proc. 29 : $60-64$.

17. — L. J. KLOTZ and T. A. DeWolfe 1971. Soil oxygen diffusion rates and mineral accumulations in citrus seedlings (citrus sinensis var. Bessie). Soil Sci. 111 : $386-392$.

18. —— - G. A. ZENTMYER and T. E. SZUSZKIEWICZ 1968. Influence of soil oxygen and soil water on the accumulation of nutrients in avocado seedlings (Persea americana Mill). Plant and Soil $29: 391-406$.

19. Letey, J., O. R. LUND, L. H. STOLZY and T. E. SZUSZKIEWICZ 1961. Plant growth, water use and nutritional response to rhizosphere differentials oxygen concentration. Soil Sci. Soc. Amer. Proc. 25 : 183-186.

20. MORITA, Y. and M. NishidA. 1953. Studies on physical properties of soils in relation to fruit tree growth II. Soil atmosphere and tree growth (6). Growth of Satsuma orange, trifoliate orange and peach seedlings and grape cuttings as influenced by various concentrations of oxygen in the soil atmosphere. J. Hort. Soc. Jap. $21: 209-215$.

21. OSKAmpmJ. and L. P. BAtJer. 1933. Soils in relation to fruit growing in New York. Part III. Some physical and chemical properties of the soils of the Hilton and Morton areas, Monroe County and their relation to orchard performance. Cornell Univ. Agr. Exp. Sta. Bull. 575 .

22. SuzUKI, T., M. KANEKo and M. TANAKA, 1967. Effects of drought period on the growth and fruiting of young citrus trees. J. Jap. Soc. Hort. Sci. $36: 389-398$.

23. Wallihan, E. F., M. J. Garber, R. G. SharPLESS and W. L. PRINTY. 1961. Effect of soil oxygen deficit on iron nutrition of orange seedlings. Plant Physiol. 36 : 425-428. 
土壤空気中の酸素濃度が温州ミカンの開花, 結実, 果実の発育, 品質に及ぼす影響

$$
\begin{aligned}
& \text { 岩 崎 一 男 } \\
& \text { (愛媛大学農学部) }
\end{aligned}
$$

\section{摘 要}

1. 4 年生温州ミカン（南柑 4 号）の鉢植結実樹を用 い, 酸素濃度を 20 (空気, $10,5,2$ および 0 (窒素ガ ス）\%に調整した空気を土壌通気して，土壤空気中の酸 素濃度が開花，結実，果実の発育，品質ならびに養分吸 収におよぼす影響をみた。

2. 発芽時から開花直前まで約 40 日間の通気処理に おいて, 酸素濃度の低下とともに, 開花は遅れ, 開花率, 結実率ともに低下し，2\%区および $0 \%$ 区では満開に至 らなかつた。
3. 結実後から収穫時むでの通気処理においては, 酸 素濃度の低下に伴つて, 樹体生長, 果実発育, 果汁中の 糖含量拈よび果皮内カロチノイド含量は低下し, 果汁中 の酸含量は増加する傾向を示した．ただし，0\%区にお ける果汁中の糖は高く，酸は低い傾向を示した．

4. 収穫時における葉内要素含量は, 酸素濃度の低下 に伴って，開花前処理区では $\mathrm{N}, \mathrm{K}$ および $\mathrm{Ca}$ が，結 実後処理区では $\mathrm{N}, \mathrm{P}, \mathrm{K}$ および $\mathrm{Ca}$ 含量がそれぞれ低 下した. 